\title{
Benchmarking of Bosnia and Herzegovina to Croatia Manufacturing Industry and Industry 4.0
}

\author{
Hadis Bajrić, Branko Vučijak, Edin Kadrić, Andrej Anđelić \\ Mechanical Engineering Faculty, Vilsonovo šetalište 9, Sarajevo, Bosnia and Herzegovina
}

\begin{abstract}
The paper presents the results of the current state of Bosnia and Herzegovina (B\&H) production companies benchmarked to the Croatian production companies and to the concept of Industry 4.0, using the same methodology formerly used in Croatia related to implementation of Industry 4.0. Assessment was made on a sample of 47 manufacturing companies from different industries. Responses were collected through online questionnaires and interviews. The assessment was made using structured questionnaire with questions related to the business processes of a company from product development, production and to the quality assurance and logistics. According to the collected responses and the methodology used, the level of development of $B \& H$ production companies is 2,19 , which is very close to the Croatian companies, in which the level of development was at 2.15, but in a survey conducted three years earlier.
\end{abstract}

This research confirmed that the level of development of $\mathrm{B} \& \mathrm{H}$ manufacturing companies is actually the same as with the Croatian companies.

Keywords - Industry 4.0; fourth industrial revolution; industries benchmarking; manufacturing industry.

DOI: 10.18421/TEM103-09

https://doi.org/10.18421/TEM103-09

Corresponding author: Hadis Bajrić,

Mechanical Engineering Faculty, Vilsonovo šetalište 9, Sarajevo, Bosnia and Herzegovina.

Email: bajric@mef.unsa.ba

Received: 23 March 2021.

Revised: 25 June 2021.

Accepted: 06 July 2021.

Published: 27 August 2021.

(cc)BY-NC-ND@ 2021 Hadis Bajric, Branko Vučijak, Edin Kadrić \& Andrej Anđelić; published by UIKTEN. This work is licensed under the Creative Commons AttributionNonCommercial-NoDerivs 4.0 License.

The article is published with Open Access at www.temjournal.com

\section{Introduction}

The industries of the most advanced countries have gone through three industrial revolutions and are progressing now to the fourth industrial revolution. After undergoing mechanization, electrification and informatization, the developed countries' industries entered the fourth phase of industrial development, referred to as "Industry 4.0".

The term "Industry 4.0" was publicly presented at the Hannover Messe in Germany in 2011 [1]. Industry 4.0 was one of ten projects under the HighTech Strategy 2020 action plan. The report of the "Industry 4.0" working group published in April 2013 defined the vision, priority areas and examples of use, so as the concept of the fourth industrial revolution, or Industry 4.0 [2].

Many authors have given their own definitions of the fourth industrial revolution or Industry 4.0. The common thesis of most definitions of Industry 4.0 is that it is a concept that involves intensive horizontal and vertical networking of all industrial components that will mutually communicate, will make analyses, decentralize decision making and take actions aiming to self-regulate and optimize [3].

Implementing each of the industrial revolutions' concepts and principles, companies have made quantum leaps in terms of all elements of competitive advantage, and the industry has had continuous growth and development. Thus, as example, productivity of US iron mining had a growth rate of $6,9 \%$ in the period $1880-1900$, and $2,5 \%$ in the period 1900-2010, which totals over 20 times in the whole period of 1880-2010 [4]. At Toyota, as a result of the development of Toyota's production system which will later be named as the Lean production, productivity in the period 1955-1985 expressed as the number of Unadjusted Vehicles per Worker increased 15 times [5].

Implementing the concepts and tools of the fourth industrial revolution will enable companies to achieve new and radical progress in terms of all elements of competitive advantages, and ensure further growth and development of the entire 
industry. Main advantages of Industry 4.0 are: increased productivity, increased confidentiality and quality, increased profits, greater agility and adaptability, greater flexibility and ability to innovate, and better user experience [6]. Main findings in [7] show that a lean organizational structure supports effective adoption of Industry 4.0 technologies, enables introduction of such technologies that are linked to development of new kind of job profiles, and supports adoption of higher levels of technology that create a higher need for non-technical competences.

The World Economic Forum's Global Lighthouse Network, consisting of 54 companies from around the world, aims to promote examples of good practices in implementing the Industry 4.0 concept. Their goal is to present how the leading companies are achieving the full potential of the fourth industrial revolution. It includes companies that have made remarkable progress in the fourth industrial revolution in internal processes, but also companies that have effectively carried out their own transformation in accordance with the principles of the fourth industrial revolution throughout the value chain. The effects of the implementation of the Industry 4.0 concept are measured with several key performance indicators, and research results are presented in Table 1 [8].

Table 1. Effects of the implementation of the Industry 4.0 concept [8]

\begin{tabular}{|l|l|c|}
\hline \multicolumn{2}{|c|}{$\begin{array}{c}\text { Key performance indicator } \\
\text { improvements }\end{array}$} & $\begin{array}{c}\text { Observed } \\
\text { impact } \\
\text { range }\end{array}$ \\
\hline \multirow{5}{*}{ Productivity } & Factory output increase & $4-200 \%$ \\
\cline { 2 - 3 } & Productivity increase & $5-160 \%$ \\
\cline { 2 - 3 } & OEE increase & $3-90 \%$ \\
\cline { 2 - 3 } & Product cost reduction & $5-40 \%$ \\
\cline { 2 - 3 } & Operating cost reduction & $2-45 \%$ \\
\cline { 2 - 3 } & Quality cost reduction & $5-90 \%$ \\
\hline \multirow{4}{*}{ Sustainability } & Waste reduction & $2-90 \%$ \\
\cline { 2 - 3 } & $\begin{array}{l}\text { Water consumption } \\
\text { reduction }\end{array}$ & $10-30 \%$ \\
\cline { 2 - 3 } & Energy efficiency & $1-50 \%$ \\
\hline \multirow{3}{*}{$\begin{array}{l}\text { Speed to } \\
\text { market }\end{array}$} & Inventory reduction & $10-90 \%$ \\
\cline { 2 - 3 } & Lead time reduction & $7-90 \%$ \\
\cline { 2 - 3 } & Changeover shortening & $30-70 \%$ \\
\hline \multirow{3}{*}{ Customization } & $\begin{array}{l}\text { Speed-to-market } \\
\text { reduction }\end{array}$ & $30-90 \%$ \\
\cline { 2 - 3 } & $\begin{array}{l}\text { Design iteration time } \\
\text { reduction }\end{array}$ & $\begin{array}{l}\text { Configuration accuracy } \\
\text { increase }\end{array}$ \\
\cline { 2 - 3 } & Lot size reduction & $15-66 \%$ \\
\hline
\end{tabular}

\section{Research Goals}

The examples of good practice presented in the previous chapter show the potential of the Industrial Revolution 4.0. The potential of the third industrial revolution can also be recognized from the abovementioned examples. Therefore, it is of great interest to make assessments of the state of industry in a country in order to define its industrial, economic, educational and other policies leading to its progress. In addition, by assessing the degree of their own development companies can get useful feedback in which business segments they lag behind the Industry 4.0 concept, which of their operations have the highest improvement potential and which are the best performing. The results of this research will also provide support to higher education institutions in creating enhanced syllabi, study programs and establishing laboratories (so-called Learning Factories) where students can encounter the tools and concept of Industry 4.0, and develop their own competencies needed for companies committed to implement this concept.

According to Veža, the average Croatian manufacturing company is at 2,15 on the scale from 1 to 4 [9], [10]. It could be expected that the level of development of $\mathrm{B} \& \mathrm{H}$ production companies is not higher, and it is of great interest to determine the most deficient areas. Comparing B\&H with Croatia also enables benchmarking of $\mathrm{B} \& \mathrm{H}$ with other $\mathrm{EU}$ countries, since Croatia, as an EU member, is included in many similar surveys. Such example is a survey conducted by Roland Berger Strategy Consultants [11], which aimed to rank EU countries according to the RB Industry 4.0 Readiness Index. According to that survey Croatia was the penultimate country in the EU, slightly above Bulgaria, with the RB Industry 4.0 Readiness Index of 1,6 on a scale from 1 to 5 .

Another example is the survey with 10 criteria used, mainly related to the use of ERP, ICT and information sharing along the supply chain, where Croatia is ranked as $18 \mathrm{th}$, with a score of 0,5330 [12]. The highest score was achieved by Denmark, which took the first place with a score of 0,8340 . This research included not only the EU member countries but also some other European countries as Turkey, Serbia, or North Macedonia, but B\&H was not included. It could be assumed that the main reason was lack of statistical data, since the research was based on the desk research approach.

According to available information, this paper is one of the first researches related to Industry 4.0 concept implementation in Bosnia and Herzegovina. The results and conclusions of the research will be useful basis for other researches in this area. The research also aims to popularize the topic of Industry 4.0 within the research institutions, industry and government policy makers. 


\section{Research Methodology and Surveyed Companies}

The research methodology applied is identical to the methodology applied in the research of Veža and others who intended to assess the level of advancement of manufacturing companies in Croatia [8], [9]. Replicating the same methodology for survey in $\mathrm{B} \& \mathrm{H}$, the same way as it was implemented in Croatia, also aimed to enable benchmarking of Croatian and $\mathrm{B} \& \mathrm{H}$ production companies. Besides, the developed methodology evaluates the real situation in companies based on the field research approach (valuating also the level of business process development of companies), which is a better-quality approach than research and assessment of the state of the industry based only on desk research approaches with certain available indicators, such as presented with the paper of Atik and Unlu [12].

Within the research, more than 350 production companies were contacted, and responses were collected from 47 companies from different industries and of different sizes, located throughout Bosnia and Herzegovina. Out of the 47 questionnaires collected, 44 companies responded to the questionnaire using the online platform, while the remaining 3 companies provided their responds with a Skype interview.

The methodology developed by Veža and others [9], [10], used to assess the level of the industry for the observed company within its area of work, is based on nine questions covering the basic companies' processes, from product development, through planning and management, production, to quality assurance, as presented in Table 2 .

Table 2. Evaluated processes

\begin{tabular}{|c|l|}
\hline No. & \multicolumn{1}{|c|}{ Area to which the question relates } \\
\hline 1. & Product development \\
\hline 2. & Degree of automation \\
\hline 3. & Work orders management \\
\hline 4. & Product traceability through production \\
\hline 5. & $\begin{array}{l}\text { Input materials inventory and work in } \\
\text { progress (WIP) inventory management }\end{array}$ \\
\hline 6. & Finished goods inventory management \\
\hline 7. & Quality management \\
\hline 8. & Product Lifecycle Management - PLM \\
\hline 9. & Green and Lean Production \\
\hline
\end{tabular}

The answers to the questions are selectable within a closed form. The respondent selects one or more offered answers that best describe the processes in his or her company. The offered answers are designed to represent belonging to one of the industrial generations. In case the respondent chooses more than one answer to a question, the arithmetic mean of the values of those answers is considered.
Thus, for example the question 8 , which concerns the traceability of products through production, offered the following answers:

(1) Industry 1.0 - There is no record of the product flow through the production process;

(2) Industry 2.0 - The product has attached paper that records when and what was done;

(3) Industry 3.0 - The product has a pasted barcode that is read manually at each workstation;

(4) Industry 4.0 - The product has an RFID tag that is automatically read at each workstation.

Detailed presentation of all offered answers representing industrial generations, as well as more detailed explanation of the scoring method, can be found in the papers of Veža and others [9], [10], sufficient level of information is also provided with the next chapter and result tables.

According to the company size, highest number of the survey responds received were from companies with 201 to 500 employees, as many as $33 \%$, while the other $67 \%$ were almost equally distributed within the smallest companies with less than 10 employees, companies with 10 to 200 employees. and those with over 500 employees.

Related to the branch of industry, most responses were collected in the field of production of finished metal products and of furniture production, which accounts for $51 \%$ of total responses, while all other fields of production account for $49 \%$ of responses.

Regarding the annual turnover, $67 \%$ of companies have an annual turnover of more than one million KM (about half a million Euro), 7\% of companies have a turnover of between half a million and a million KM, while other companies have a turnover of less than half a million.

The most of the surveyed companies are those producing individual products and small series for a known customer (61,7\% of companies), followed by companies that have serial and large series production for an unknown customer $(31,92 \%$ of companies). The remaining companies produce modular products, and only one company offers the possibility of configuring the product using the established Web shop.

\section{Survey Results}

The Survey results grouped by questions are presented in Tables 3 to 11, as follows:

- Average level of B\&H industry towards product development is presented in Table 3;

- Average level of B\&H industry according to the automation of the technology used is presented in Table 4;

- Average level of $\mathrm{B} \& \mathrm{H}$ industry towards work order management is presented in Table 5; 
- Average level of B\&H industry according to product tracking through production process is presented in Table 6;

- The average level of B\&H industry according to material inventory management and WIP is presented in Table 7;

- The average level of B\&H industry according to inventory management of finished products is presented in Table 8;

- The average level of B\&H industry according to quality assurance is presented in Table 9;

- The average level of B\&H industry according to product life cycle management is presented in Table 10;
- Average level of B\&H industry according to the application of TPS and GALP principles is presented in Table 11.

Each table relates to responds to just one of the questions, presenting the question itself, possible answers, the number of answers, the number of points that represents affiliation to the appropriate industry generation, and the final result that represents the arithmetic mean of all answers. The final number of points represents the level of industry development by given area of work.

Table 3. Average level of $B \& H$ industry towards product development

\begin{tabular}{|l|c|c|c|}
\hline \multicolumn{1}{|c|}{ Answers } & $\begin{array}{c}\text { Number of } \\
\text { responses }\end{array}$ & $\begin{array}{c}\text { Points per } \\
\text { answer }\end{array}$ & $\begin{array}{c}\text { Final number } \\
\text { of points }\end{array}$ \\
\cline { 1 - 2 } Product development takes place using CAD systems & 36 & 1,5 & \\
\cline { 1 - 2 } Use of Digital Factory and simulation in product development & 1 & 3 & \multirow{2}{*}{1,54} \\
\cline { 1 - 2 } $\begin{array}{l}\text { Virtual Reality, 3D scanning and rapid prototyping are used in product } \\
\text { development }\end{array}$ & 0 & 4 & \\
\cline { 1 - 2 } None of the above & 6 & $/$ & \\
\hline
\end{tabular}

Table 4. Average level of $B \& H$ industry according to the automation of the technology used

\begin{tabular}{|c|c|c|c|}
\hline Answer & $\begin{array}{c}\text { Number of } \\
\text { responses }\end{array}$ & $\begin{array}{c}\text { Points per } \\
\text { answer }\end{array}$ & $\begin{array}{c}\text { Final number } \\
\text { of points }\end{array}$ \\
\hline Manual processing and / or manual assembly & 17 & 1 & \multirow{4}{*}{2,29} \\
\hline Combination of manual manufacturing and $\mathrm{CNC}$ machines & 4 & 2 & \\
\hline CNC machine tools and / or automated production line & 18 & 3 & \\
\hline $\begin{array}{l}\text { Modern production centres with automated transport and / or robotic } \\
\text { stations on an automated production line }\end{array}$ & 6 & 4 & \\
\hline
\end{tabular}

Table 5. Average level of $B \& H$ industry towards work order management

\begin{tabular}{|c|c|c|c|}
\hline Answer & $\begin{array}{c}\text { Number of } \\
\text { responses }\end{array}$ & $\begin{array}{c}\text { Points per } \\
\text { answer }\end{array}$ & $\begin{array}{c}\text { Final number } \\
\text { of points }\end{array}$ \\
\hline $\begin{array}{l}\text { Oral communication man to man (competent person explains work } \\
\text { order to workers) }\end{array}$ & 5 & 1 & \multirow{5}{*}{2,32} \\
\hline $\begin{array}{l}\text { Written communication man to man (competent person submits a } \\
\text { written work order to the employee) }\end{array}$ & 30 & 2 & \\
\hline $\begin{array}{l}\text { Human-machine communication (worker controls CNC machine } \\
\text { tools) or production line }\end{array}$ & 4 & 3 & \\
\hline Machine to machine communication & 0 & 3 & \\
\hline Intranet communication (own computer network) & 8 & 4 & \\
\hline
\end{tabular}

Table 6. Average level of B\&H industry according to product tracking through production process

\begin{tabular}{|l|c|c|c|}
\hline \multicolumn{1}{|c|}{ Answer } & $\begin{array}{c}\text { Number of } \\
\text { responses }\end{array}$ & $\begin{array}{c}\text { Points per } \\
\text { answer }\end{array}$ & $\begin{array}{c}\text { Final number } \\
\text { of points }\end{array}$ \\
\hline $\begin{array}{l}\text { There is no record of the product passing through the production } \\
\text { process }\end{array}$ & 12 & 1 & \\
\cline { 1 - 2 } $\begin{array}{l}\text { The product has attached paper which writes when and what was } \\
\text { done }\end{array}$ & 24 & 2 & \multirow{2}{*}{1,98} \\
\hline The product has a glued barcode read manually at each workplace & 7 & 3 & \\
\cline { 1 - 2 } $\begin{array}{l}\text { The product has an RFID tag that is automatically read at each } \\
\text { workplace }\end{array}$ & 2 & 4 & \\
\cline { 1 - 2 } None of the above & 1 & $/$ & \\
\hline
\end{tabular}


Table 7. The average level of B\&H industry according to material inventory management and WIP

\begin{tabular}{|c|c|c|c|}
\hline Answer & $\begin{array}{c}\text { Number of } \\
\text { responses }\end{array}$ & $\begin{array}{c}\text { Points per } \\
\text { answer }\end{array}$ & $\begin{array}{c}\text { Final number } \\
\text { of points }\end{array}$ \\
\hline $\begin{array}{l}\text { Based on the available (recorded) data, one can estimate to some } \\
\text { extent how much raw materials, parts and products one currently has } \\
\text { in the input warehouse and individual intermediate warehouses in } \\
\text { production. }\end{array}$ & 14 & 1.50 & \multirow{3}{*}{2,67} \\
\hline $\begin{array}{l}\text { Using the database on the computer server, one can read how much } \\
\text { raw materials, parts and products one currently has in the input } \\
\text { warehouse, and individual intermediate warehouses in production. }\end{array}$ & 30 & 3 & \\
\hline $\begin{array}{l}\text { Using the application on our phone or tablet, one can read how much } \\
\text { raw materials, parts and products one currently has in the input } \\
\text { warehouse and individual intermediate warehouses in production. }\end{array}$ & 5 & 4 & \\
\hline
\end{tabular}

Table 8. The average level of B\&H industry according to inventory management of finished products

\begin{tabular}{|c|c|c|c|}
\hline Answer & $\begin{array}{l}\text { Number of } \\
\text { responses }\end{array}$ & $\begin{array}{l}\text { Points per } \\
\text { answer }\end{array}$ & $\begin{array}{l}\text { Final number } \\
\text { of points }\end{array}$ \\
\hline $\begin{array}{l}\text { Based on the available (recorded) data, one can estimate to some } \\
\text { extent how many finished products one currently has in stock }\end{array}$ & 12 & 1,50 & \multirow{4}{*}{2,70} \\
\hline $\begin{array}{l}\text { Using the database on the computer server, one can read how many } \\
\text { finished products one currently has in stock }\end{array}$ & 30 & 3 & \\
\hline $\begin{array}{l}\text { Using the app on your phone or tablet, one can read how many } \\
\text { finished products one currently has in stock }\end{array}$ & 4 & 4 & \\
\hline None of the above & 1 & 1 & \\
\hline
\end{tabular}

Table 9. The average level of B\&H industry according to quality assurance

\begin{tabular}{|c|c|c|c|}
\hline Answer & $\begin{array}{l}\text { Number of } \\
\text { responses }\end{array}$ & $\begin{array}{l}\text { Points per } \\
\text { answer }\end{array}$ & $\begin{array}{l}\text { Final number } \\
\text { of points }\end{array}$ \\
\hline Product control at the end of the production process & 3 & 1 & \multirow{5}{*}{2,40} \\
\hline Interphase control throughout the process & 23 & 2 & \\
\hline $\begin{array}{l}\text { Quality management according to the concept of total quality } \\
\text { management (TQM) }\end{array}$ & 7 & 3 & \\
\hline Quality management according to ISO 9000 & 13 & 3 & \\
\hline Quality management according to the Six Sigma concept & 1 & 4 & \\
\hline
\end{tabular}

Table 10. The average level of B\&H industry according to product life cycle management

\begin{tabular}{|c|c|c|c|}
\hline Answer & $\begin{array}{l}\text { Number of } \\
\text { responses }\end{array}$ & $\begin{array}{l}\text { Points per } \\
\text { answer }\end{array}$ & $\begin{array}{c}\text { Final number } \\
\text { of points }\end{array}$ \\
\hline $\begin{array}{l}\text { There is a division into departments according to functions PC and } \\
\text { software are located in individual departments (CAD, CAM, CAD, } \\
\text { PPC) }\end{array}$ & 17 & 2 & \multirow{4}{*}{1,87} \\
\hline $\begin{array}{l}\text { Individual departments are connected through Computer Integrated } \\
\text { Manufacturing (CIM) }\end{array}$ & 7 & 3 & \\
\hline $\begin{array}{l}\text { Integration of PLM, Enterprise Resource Planning (ERP) and } \\
\text { Management Execution System (MES) through the Information } \\
\text { Backbone and Cloud }\end{array}$ & 3 & 4 & \\
\hline We are not familiar with PLM & 19 & 1 & \\
\hline
\end{tabular}

Table 11. Average level of B\&H industry according to the application of TPS and GALP principles

\begin{tabular}{|c|c|c|c|}
\hline Answer & $\begin{array}{c}\text { Number of } \\
\text { responses }\end{array}$ & $\begin{array}{c}\text { Points per } \\
\text { answer }\end{array}$ & $\begin{array}{c}\text { Final number } \\
\text { of points }\end{array}$ \\
\hline Neither TPS nor GALP principles are used & 33 & 1,50 & \multirow{3}{*}{1,97} \\
\hline $\begin{array}{l}\text { Some elements of TPS and GALP are used (e.g. Just in time, Value } \\
\text { Stream Mapping, etc.) }\end{array}$ & 9 & 3 & \\
\hline $\begin{array}{l}\text { TPS and GALP principles were introduced throughout the business } \\
\text { process - the so-called Lean Management } 2.0\end{array}$ & 3 & 4 & \\
\hline
\end{tabular}


Based on all collected answers and according to the applied methodology, the average production company in $\mathrm{B} \& \mathrm{H}$ belongs to the second industrial generation with an average result of 2,19 . Table 12 and Figure 1 present the average level of development of individual segments of $\mathrm{B} \& \mathrm{H}$ industry.

The most deficient business segments are product development and product lifecycle management. In addition to these two, B\&H industry is also deficient in the segments of product life cycle management, implementation of the principles of green and lean production, and product traceability through production. All these segments have a total score below 2.

Other segments achieved scores above 2, and B\&H industry has the best result in terms of inventory management of finished products, and inventory management of inputs and work in progress inventories (WIP).

Table 12. Average level of development of $B \& H$ production companies in relation to Industry 4.0

\begin{tabular}{|c|c|c|}
\hline Question & $\begin{array}{c}\text { Number of points per } \\
\text { question }\end{array}$ & $\begin{array}{l}\text { Industry average in } \\
\mathbf{B} \& \mathbf{H}\end{array}$ \\
\hline Product development & 1,54 & \multirow{9}{*}{2,19} \\
\hline Degree of automation & 2,29 & \\
\hline Work order management & 2,32 & \\
\hline Product traceability through production & 1,98 & \\
\hline $\begin{array}{l}\text { Input materials inventory and work in progress (WIP) inventory } \\
\text { management }\end{array}$ & 2,67 & \\
\hline Finished goods inventory management & 2,70 & \\
\hline Quality management & 2,40 & \\
\hline Product Lifecycle Management - PLM & 1,87 & \\
\hline Green and Lean Production & 1,97 & \\
\hline
\end{tabular}

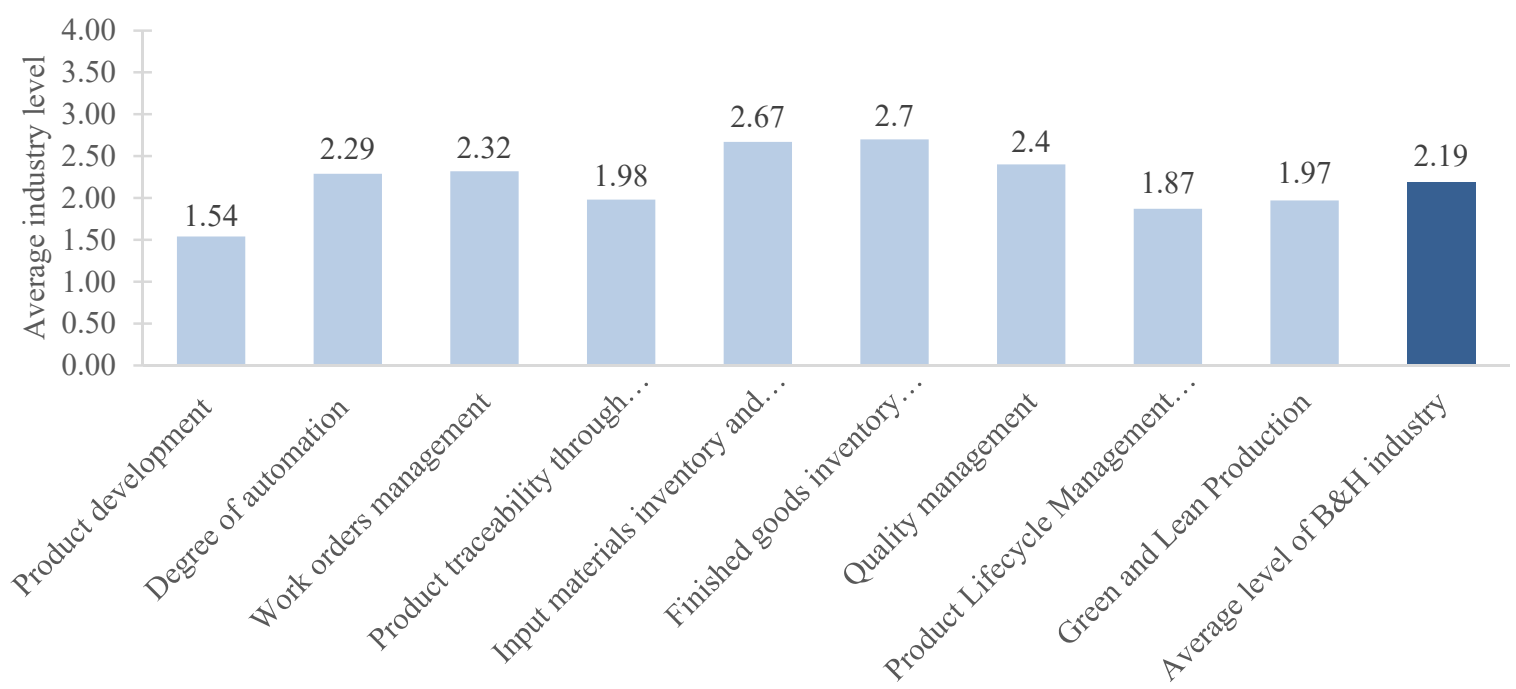

Figure 1. Average level of industry in Bosnia and Herzegovina

From Figure 2 it is interesting to note that, as a rule, the development of a company depends on the size of the company. It can be concluded that the larger the company, the higher the level of industrial development. Thus, companies with less than 50 employees are at the level of development between the first and second industrial revolution, while companies with more than 50 employees have the level of development between the second and third industrial revolution. Companies with over 500 employees are the best placed with an average score of 2,72 .

Figure 3 shows the distribution of companies according to the degree of development. The class width on the graph is 0,25 . It is interesting to note that most companies are classified in one class below and one class above the value 2 . It can also be seen that only four companies had a score above 3 , and only one company has a maturity above 3,5 , and it can be considered a company ready for Industry 4.0. 


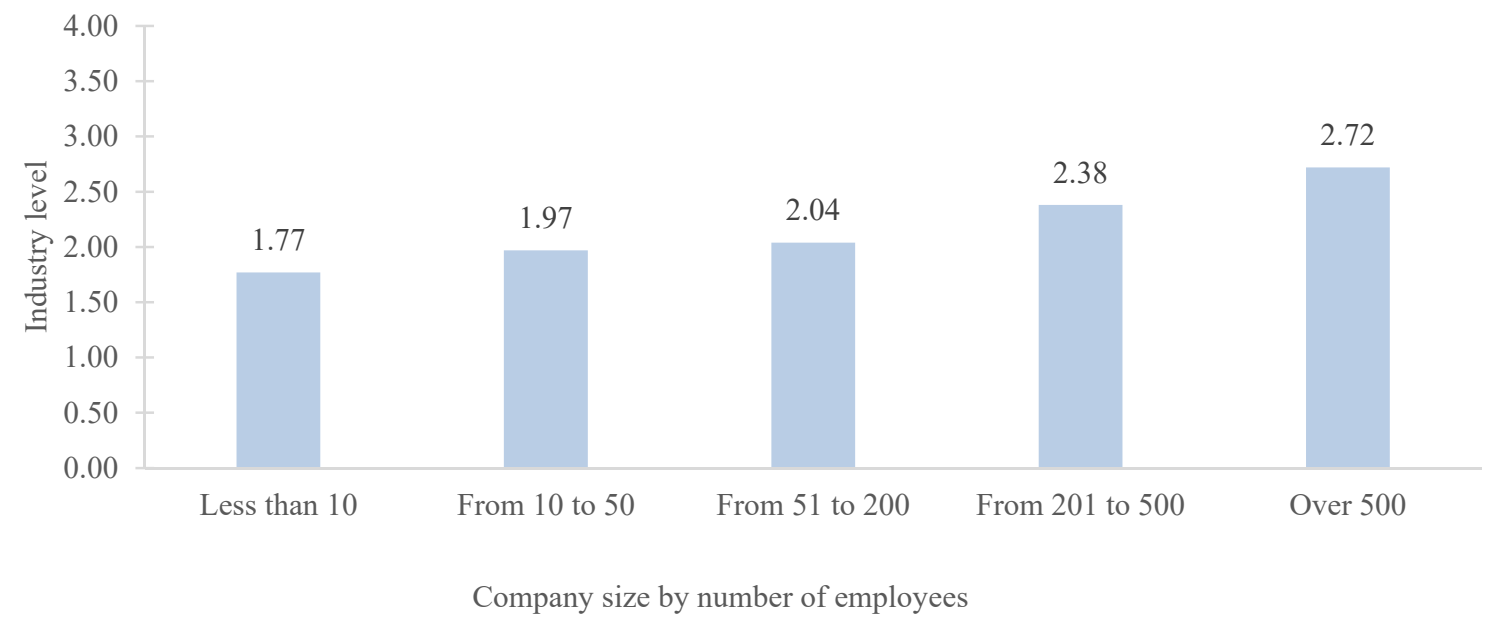

Figure 2. Distribution of companies by size of the company

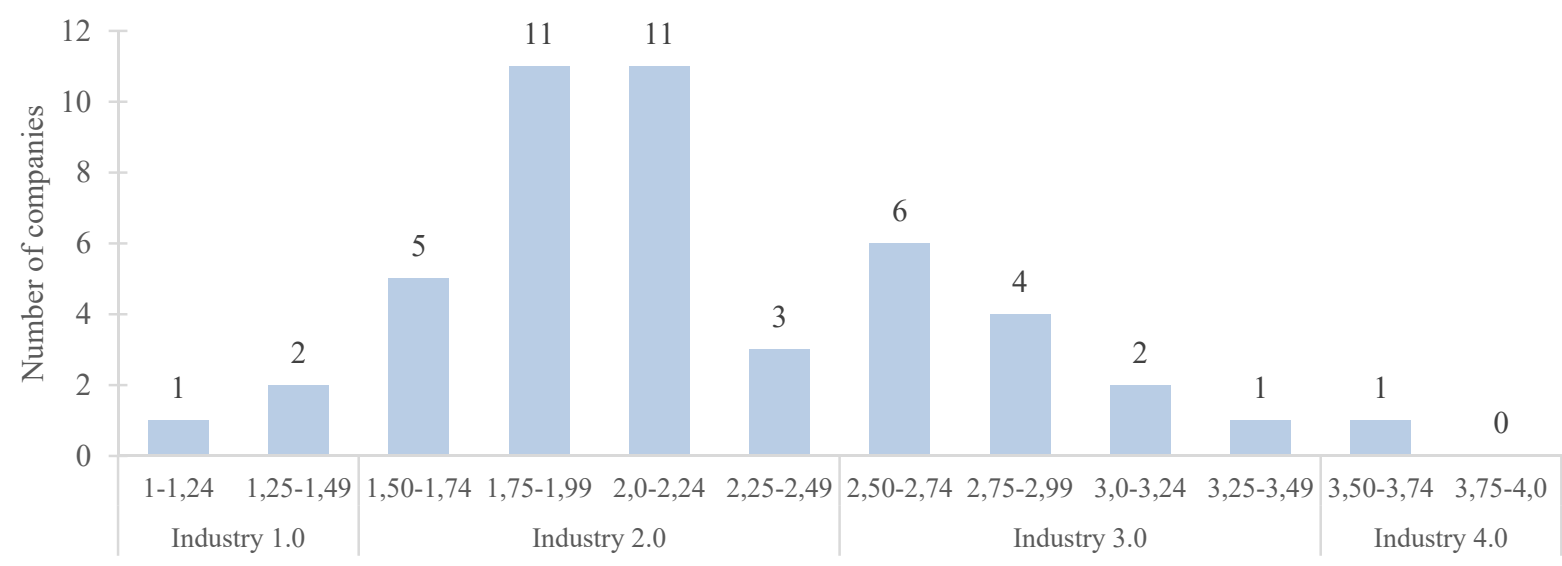

Figure 3. Distribution of companies according to industrial maturity

\section{Conclusion and Recommendations}

The average $\mathrm{B} \& \mathrm{H}$ manufacturing company, in terms of the level of development in relation to Industry 4.0, is still at the second industrial revolution with a quantified level of 2,19. The research was done in 2019 and included a sample of 47 manufacturing companies that responded to survey, of different sizes and from different industries, located throughout $\mathrm{B} \& \mathrm{H}$.

According to a survey conducted in 2015 in Croatia, in which the same methodology was used as for this survey, the average manufacturing company in Croatia is also in the second industrial revolution with a quantified development level of 2,15 [9], [10]. Deficient segments of manufacturing companies in $\mathrm{B} \& \mathrm{H}$, such as product development, product traceability through production, application of green and lean production, are also deficient in manufacturing companies in Croatia. Business segments in which $\mathrm{B} \& \mathrm{H}$ companies are somewhat more competitive are also better positioned in Croatian companies. B\&H industry achieved a slightly better result compared to the Croatian, but considering that the research in Croatia was done in 2015 , and in B\&H it was done in 2019, it can be concluded that the level of development of manufacturing companies in these two countries is approximately the same, and that this is the level of the second industrial revolution.

According to survey conducted by Roland Berger Strategy Consultants [11], which aimed to rank EU countries according to the RB Industry 4.0 Readiness Index, Croatia ranked penultimate among all EU countries. The only lagging country was

Bulgaria. Industry 4.0 Readiness Index of Croatia was valuated with 1,6 on a scale from 1 to 5 . Based on this research and benchmarking with Croatia, it could be concluded that B\&H industry according to the level of development is located at the very rear compared to European countries. 
One of the conclusions is that smaller companies are less developed and lag behind the latest industry trends, while the only B\&H company with a score above 3,5 is a company with over 500 employees and it is owned by an international corporation based in Germany. It should be noted that private companies predominantly participated in the survey, in addition, the questionnaire was filled out by companies that have a culture of answering questionnaires and they are mostly better developed companies, which leads to the conclusion that the average maturity of manufacturing companies in $\mathrm{B} \& \mathrm{H}$ is probably even lower that achieved 2,19. But the same consideration with the same conclusion applies to the Croatian industry [9], [10].

The methodology used in this paper is a very good starting point for a realistic assessment of the level of development of industrial companies. The methodology could be further refined with processes that are not well enough covered, such as supply chain management. In addition, there is still a lot of space to develop a generic methodology that could be also applied to service companies or companies from specific industries, such as pharmaceuticals, food, agriculture, and etc. Also, it would be very interesting to repeat the same research with an interval of one or more years, what would enable monitoring of actual progress of the industry development and more effective guiding of such progress, underlining the needed higher education enhancements in that sense.

\section{References}

[1]. Pfeiffer, S. (2017). The vision of "Industrie 4.0" in the making - a case of future told, tamed, and traded. Nanoethics, 11(1), 107-121. https://doi.org/10.1007/s11569-016-0280-3

[2]. Liao, Y., Loures, E. R., Deschamps, F., Brezinski, G., \& Venâncio, A. (2018). The impact of the fourth industrial revolution: a cross-country/region comparison. Production, 28, 1-18.

https://doi.org/10.1590/0103-6513.20180061

[3]. Piccarozzi, M., Aquilani, B., \& Gatti, C. (2018). Industry 4.0 in Management Studies: A Systematic Literature Review. Sustainability, 10(10), 1-24. https://doi.org/10.3390/su10103821

[4]. Humphreys, D. (2020). Mining productivity and the fourth industrial revolution. Mineral Economics, 33(1), 115-125.

https://doi.org/10.1007/s13563-019-00172-9.

[5]. Cusumano, M. A. (1988). Manufacturing innovation: lessons from the Japanese auto industry. MIT Sloan Management Review, 30(1), 29.

[6]. Sima, V., Gheorghe, I. G., Subić, J., \& Nancu, D. (2020). Influences of the Industry 4.0 Revolution on the Human Capital Development and Consumer Behavior: A $\quad$ Systematic Review. Sustainability, 12(10), 1-28. https://doi.org/10.3390/SU12104035

[7]. Cimini, C., Boffelli, A., Lagorio, A., Kalchschmidt, M., \& Pinto, R. (2021). How do industry 4.0 technologies influence organisational change? An empirical analysis of Italian SMEs. Journal of Manufacturing Technology Management, 32(3), 695721. https://doi.org/10.1108/JMTM-04-2019-0135

[8]. World Economic Forum, (2019). Global Lighthouse Network: Insights from the Forefront of the Fourth Industrial Revolution. Retrieved from: http://www3.weforum.org/docs/WEF_Global_Lighth ouse Network.pdf [accessed: 10 October 2020].

[9]. Veza, I., Mladineo, M., \& Peko, I. (2015). Analysis of the current state of Croatian manufacturing industry with regard to industry 4.0. In Proceedings of the 15th International Scientific Conference on Production Engineering-CIM'2015: Computer Integrated Manufacturing and High Speed Machining, Vodice, Croatia, 10-13 June 2015.

[10]. Veza, I., Mladineo, M., \& Gjeldum, N. (2016). Selection of the basic lean tools for development of croatian model of innovative smart enterprise. Tehnički vjesnik, 23(5), 1317-1324. https://doi.org/10.17559/TV-20160202120909

[11]. Roland Berger Strategy Consultants. (2014). Industry 4.0: The new industrial revolution-How Europe will succeed. Retrieved from: http://www.iberglobal.com/files/Roland Berger_Ind ustry.pdf [accessed: 10 October 2020].

[12]. Atik, H., \& Ünlü, F. (2019). The measurement of industry 4.0 performance through industry 4.0 index: an empirical investigation for Turkey and European countries. Procedia Computer Science, 158, 852-860. https://doi.org/10.1016/j.procs.2019.09.123 